\title{
$\mathrm{ECDIS}$ 에 의한 준설선의 작업공정 관리 및 평가 \\ 이대재*
}

부경대학교 해양생산시스템관리학부

\section{Evaluation and management of work process in dredger using ECDIS}

\author{
Dae-Jae LEE* \\ Division of Marine Production System Management, \\ Pukyong National University, Busan 608-737, Korea
}

This paper describes on the evaluation and management of work process in suction hopper dredger and grab bucket dredger as an application of a PC-based ECDIS system. The dynamic tracking of dredging bucket and the data logging of grab dredging information were performed by using the grab dredging vessel "Kunwoong G-18". The position and route tracking of the dredger moving toward the ocean dumping site of dredged material was performed by using the hopper dredging vessel "Samyang-7". The evaluation of wok process in the dredging field, for grab dredger, was continuously carried out on January to May, 2006, in Incheon Hang and for hopper dredger, on July to December, 2003, in Busan Hang, Korea. The dredging information, such as dredger's position, heading, dredging depth and route track which was individually time stamped during the dredging operation, was automatically processed in real-time on the ECDIS and displayed simultaneously on the S-57 ENC chart. From these results, we conclude that the ECDIS system can be applied as a tool in order to manage the work process during the dredging operation, and also in order to generate the factual record of the dredging activities that is sufficient for dredging inspector to accurately evaluate the contract performance even in the absence of a full-time onboard inspector.

Key words : Suction hopper dredger, Grab bucket dredger, ECDIS, Evaluation and management of work process.

$$
\text { 서 론 }
$$

현재 세계적으로 선박이 점차 대형화되고, 이 들 선박이 우리나라 주요 항만을 빈번하게 입항
및 출항하는 관계로 선박의 안전을 확보하기 위 한 항로 및 항만 준설공사가 부산항, 광양항, 인 천항, 평택항 및 부산 신항만 등에서 활발하게

\footnotetext{
*Corresponding author: daejael@pknu.ac.kr, Tel: 82-51-620-6116, Fax: 82-51-622-8145
} 
진행되고 있다. 일반적으로, 항로나 항만의 준설 공사가 완료되면, 수급자는 수심측량 결과를 기 초로 수심도를 작성하여 수심측량 성과표를 제 출하게 되는 데, 이때, 준설성과의 과학적 평가 를 위해서는 준설공정을 실시간으로 모니터링 하면서 작업공정을 관리하고 평가할 수 있는 시 스템의 구축이 필요하다. 즉, 준설기능 및 상황, 준설 track, 준설수심 및 준설 토사량 등을 실시 간 모니터링 할 수 있는 준설관리시스템을 구비 하여 작업자 및 관리자가 작업정보를 상호 공유 할 필요가 있다(Jung, 2006; IHC Systems BV, 2000; SAM Electronics GmbH, 2007).

Grab 준설은 bucket을 수중의 준설 위치에 내 려 수면위로 준설토를 퍼 올리는 방식으로서 보 통 큰 힘이 요구되므로 선체를 스퍼드(spud)로 고정시킨 후, crane을 선회시키면서 작업을 수행 해야 하므로 시시각각 bucket이 투하되는 위치 및 깊이를 파악해야 한다. 반면, Hopper 준설은 흡인장치가 붙은 suction arm을 준설위치에 내려 놓고 자항으로 전진하면서 비교적 광범한 구역 의 준설토를 흡입하는 방식이므로 흡입구의 위 치 및 깊이를 실시간으로 파악할 필요가 있다. 또한, grab 준설에서는 준설토를 바지 운반선에 적재하여 예인선으로 투기장까지 운반하여 투 기하지만, hopper 준설에서는 직접 준설선이 해 상 투기장으로 운반하여 투기한다. 이 때, 준설 선이 지정된 준설 투기장으로 이동하는 동적 거 동 및 준설 예정구역으로 다시 복귀하는 예상시 간을 파악하여 인근을 통항하는 선박에 의해 준 설작업에 지장이 초래되지 않도록 해야 하는 데, 이를 위해서는 해당 선박의 원격모니터링이 필 요하다.

본 연구에서는 이와 같은 준설선에 있어서의 작업공정을 과학적으로 관리 및 평가하기 위한 기초연구로써, ECDIS(electronic chart display and information system)를 이용하여 hopper 및 grab 준선설의 작업공정을 실시간으로 모니터링하면 서 작업의 양과 상태를 $\mathrm{ENC}$ 해도상에 표시하고,
이 정보를 작업자와 관리자가 함께 공유할 수 있 도록 함으로써 작업일정의 수립 및 평가에 필요 한 정보를 제공하고자 하였다.

\section{재료 및 방법}

Hopper 준설선의 모니터링 시스템

Hopper 준설작업의 모니터링은 Fig. 1 에서와 같이 2003년 7월부터 12월까지 부산항에서 삼양 7호(삼양개발)에 마린전자에서 개발한 준설관 리시스템을 탑재하여 수행 하였다(MECys, 2006).

준설선에서 준설토를 흡입하는 suction head의 깊이, 즉, 준설수심은 dredge head depth indicator (Model 3602, Accurate Measurement Ltd)를 사용 하여 측정하였다. 실험에서는 소형 압축기에서 송출되는 공기압을 갑판상의 측정 unit에 장착 된 공기 horse를 통해 수중 suction head에 공급하 면서 준설선의 이동에 따라 변화하는 suction head 위치에 대한 압력을 실시간으로 측정하였 다. 본 실험에 사용한 dredge head depth indicator 에서 검출 가능한 최소 및 최대 압력은 각각 $0.1 \mathrm{bar}, 2.8 \mathrm{bar}$ 이고, 현장에서 측정된 수압은 깊 이로써 환산되어 RS232C interface를 통해 $9600 \mathrm{baud}, 2 \mathrm{~Hz}$ 시간간격으로 출력된다. 준설 작 업시 suction head 깊이의 측정정도를 높이기 위 해 실험을 행하기 전에 현장에서 suction head측 horse를 알고 있는 깊이의 수층에 내려 calibration

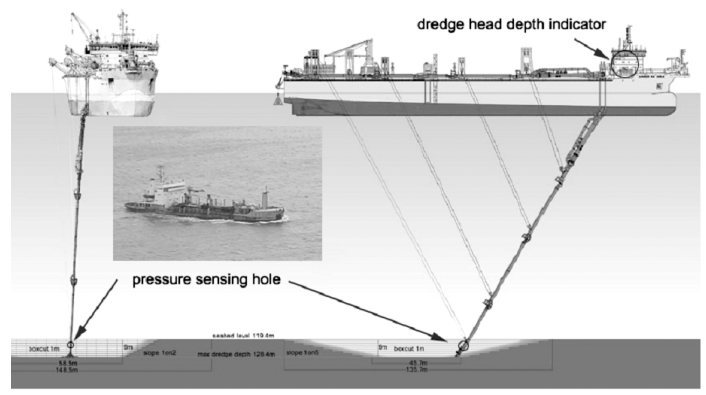

Fig. 1. Schematic view of the dredging operation by hopper dredger (Samyang - 7) in Busan Hang on July to December, 2003. 
표를 작성하여 이용하였다. 이렇게 측정된 suction head에서의 압력과 갑판상의 압력의 차에 상당하는 준설수심이 dredge head depth indicator 에서 출력되면, 이 값을 ECDIS에 입력하여 처리 하였다. 또한, 준선선의 작업 $\operatorname{track}$ 은 DGPS(AG 132, Trimble) 위치를 이용하여 도시하였고, 준설 토가 흡입되는 suction head의 위치는 선체 중심 으로부터 선수미 방향과 정횡 방향에 대한 위치 의 편위량을 DGPS 위치에 가감하여 산출하였 다. 또한, 준설선이 진행하는 선수방 위는 gyrocompass(RGC - 50, Simrad)로부터 출력되는 NMEA0183 데이터를 제공받아 suction head의 위치와 함께 ECDIS에 입력, 처리하였다.

\section{$\mathrm{Grab}$ 준설선의 모니터링 시스템}

$\mathrm{Grab}$ 준설작업의 모니터링은 인천항에서 Fig. 2에서와 같이 2006년 1월부터 6월까지 건웅산업 (주)의 건웅 $\mathrm{G}-16$ 호(G/T 649ton, $1600 \mathrm{ps})$ 를 사 용하여 행하였다.

준설선의 선교에 설치된 $\mathrm{ECDIS}$ (이하 선교 $\mathrm{ECDIS}$ 라 한다)에서는 먼저 선교 상부갑판의 중 앙부에 선수미선과 직각인 좌현과 우현 방향으 로 같은 간격의 위치에 설치된 2 개의 DGPS
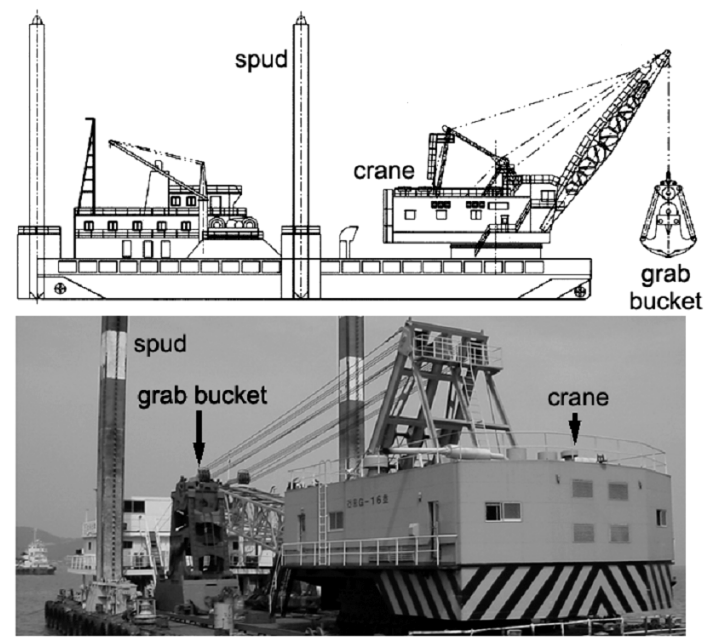

Fig. 2. Schematic view of the dredging operation by grab dredger (Kunwoong G - 18) in Incheon Hang on January to May, 2006.
(AG - 132, Trimble)로부터 위치, $\mathrm{COG}, \mathrm{SOG}$ 등 의 NMEA 신호가 입력되면, 이들 신호로부터 준 설선의 진침로, 준설선의 중심위치좌표, 크레인 의 위치좌표 등을 산출하였다(Lu et al., 1994; Darren, 1998). 이들 침로와 좌표신호는 선교 ECDIS의 serial port로 출력되어 무선 랜 $(\mathrm{RG}-$ $3000 \mathrm{~A}$, Anygate)의 지향성 안테나(이득 $12 \mathrm{~dB}$ )를 통해 크레인 상부갑판에 설치된 동일 무선 랜의 무지향성 안테나(이득 $6 \mathrm{~dB}$ )를 경유하여 크레인 조종실에 설치된 $\mathrm{ECDIS}$ (이하 조종실 $\mathrm{ECDIS}$ 라 한다)에 입력시켜 화면상에 실시간으로 표시하 였다.

반면, 조종실 ECDIS에서는 크레인 boom 상 부, 즉 $\mathrm{grab}$ 의 직상에 설치된 DGPS로부터 위치, $\mathrm{COG}, \mathrm{SOG}$ 등의 NMEA 신호를 입력받아 이들 신호로부터 grab의 위치, 선수미선에 대한 grab 의 방향, mark 위치좌표, grab의 깊이(준설수심) 등을 산출하였다. 이들 조종실 ECDIS에서 추출 된 정보는 선교 ECDIS에서와 동일한 방법으로 serial port로 출력되어 무지향성 무선 랜의 안테 나를 통해 크레인 상부갑판에 설치된 지향성 무 선 랜의 안테나를 경유하여 선교 ECDIS에 입력 시켜 화면상에 실시간으로 표시하였다. 준설선 에는 grab나 hammer를 수중에 투하하거나 수중 에서 인양하기 위한 윈치와 grab를 열거나 닫기 위한 윈치가 설치되어 있는 데, 본 연구에서는 이들 윈치에 각각 up/down counter를 장치하여 $\mathrm{grab}$ 의 안전한 개폐와 준설수심 등에 관한 정보 를 수집하였다. 특히, 준설수심은 먼저 grab를 닫 은 상태에서 내려 grab의 하단이 수면에 접하였 을 때를 수심 “0"m 로 설정하고, grab를 열어 수 중에 투하한 후, grab가 해저에 접지한 상태에서 $\mathrm{grab}$ 개폐 윈치를 가동하여 grab를 완전히 폐쇄 하고, 조종실 $\mathrm{ECDIS}$ 를 이용하여 해당 위치에 mark를 표시하면, 이 순간 grab 개폐조작윈치에 설치된 up/down conter 값이 NMEA converter (ZNC-401, Zinnos)를 통해 NMEA0183 data format의 준설수심으로 변환되고, 이 정보는 
$\mathrm{grab}$ 위치좌표, 선수미선에 대한 상대방위 등의 정보와 함께 조종실 ECDIS에 수록, 처리된다.

grab 준설선이 bucket을 해중에 투하하여 해저 를 준설하는 면적의 위치좌표는 bucket의 평면위 치좌표, bucket의 크기 및 bucket의 방향각 등을 이용하여 계산한 후, bucket이 투하될 때마다 측 정되는 준설된 수심을 컬러 패턴으로 변환하여 준설 소해 해저면의 깊이를 실시간으로 조석을 보정하여 ECDIS의 ENC 화면상에 나타내었다.

\section{결과 및 고찰}

현재, 대부분의 준설선에서는 준설 공정의 관 리, 준설 기계의 작동과 제어, 준설위치 및 준설 토사량 등을 실시간으로 모니터링하기 위해 독 자적으로 개발한 준설 관리시스템이나, 또는 상 용의 준설 관리시스템을 이용하고 있다. 본 연구 에서는 국제해사기구의 규정에 따라 항해의 안 전을 확보하기 위해 개발, 보급되고 있는 선박용 GIS(Geographical Information System), 즉 PC based ECDIS 시스템을 이용하여 hopper 준설선 의 작업공정을 관리 및 평가하기 위한 현장실험 을 수행하였다. 즉, hopper 준설선이 준설 현장에 서 계획된 route를 따라 자력으로 이동하면서 해 저의 준설토를 흡입하여 hopper에 적재하는 작 업을 수행하는 동안, 준설선의 이동궤적, 침로 및 속력, 준설 위치 및 깊이 등에 대한 작업공정 요소를 실시간으로 모니터링하였다. 또한, 준설 작업 후, 자항으로 해양 투기장까지 준설토를 운 반할 때, 준설선의 이동항로를 추적, 관리하기 위해 모든 이동상황에 대한 동적 거동을 실시간 으로 모니터링하였다.

본 연구의 준설 대상해역인 부산 자성대 콘테 이너 부두 외측에 있어서는 실험당시 해저 준설 토의 두께가 매우 두꺼워 계획된 준설수심을 한 번의 suction 준설로써 달성하기 어려웠기 때문 에 계획수심이 달성될 때까지 hopper 준설선을 연속적으로 이동시키면서 수회에 걸쳐 동일한 지 점을 반복적으로 준설하였는데, 그 결과는
Fig. 3 과 같다. Fig. 3은 suction hopper 준설선 삼 양 7호가 2003년 7월 - 12월에 부산 자성대 콘테 이너 부두 외측에 대한 증심준설공사에 대한 공 정내용을 나타낸 성과도의 일례로써, 본 연구에 서는 준설선의 이동 route에 일정 시간간격의 time tag를 붙이고, 또한, suction head의 이동에 따른 각 준설 깊이를 컬러 밴드로써 표기하여 현 재의 준설공정의 진도를 실시간으로 파악할 수 있도록 하였다.

Fig. 3에서 ENC 해도 상에서 가는 실선으로 남 북으로 표시된 준설선의 궤적은 준설선이 준설 한 준설토가 hopper에 가득 적재된 경우, 해상의 지정된 준설토 투기장으로 자력으로 이동하여 준설토를 투기하게 되는 데, 이 때, 준설선이 준 설현장과 해양 투기장을 왕래한 궤적을 나타낸 것이다. 여기서는 일정시간 간격으로 준설일자 와 시간을 함께 표기하여 준설공정의 관리가 효 율적으로 수행될 수 있도록 하였다. 또한, 준설 토를 투기하거나 혹은 투기 후 준설구역으로 선 박을 이동할 경우에는 준설 계획도상 준설예정 구역과 예상시간 등을 준설 관계자들이 ECDIS 상에서 자동적으로 확인 할 수 있도록 함으로써, 준설시간의 지연이나 통항선박에 지장이 발생 하지 않도록 하였다.

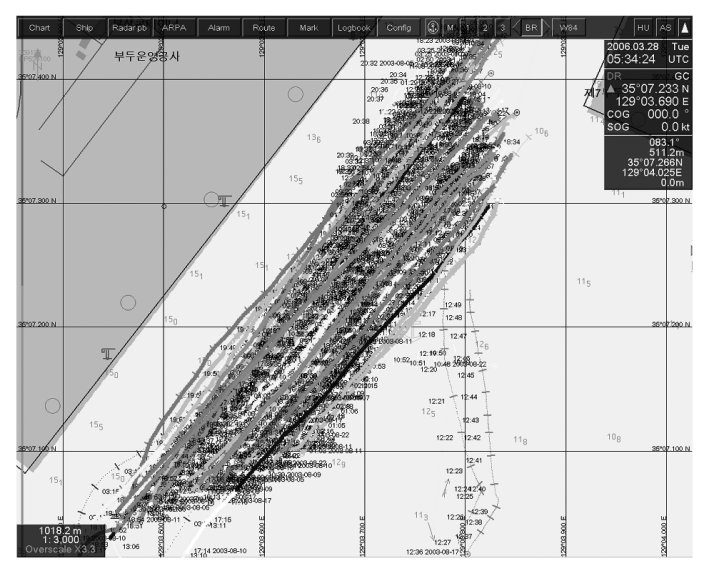

Fig. 3. An example of the real-time monitoring record of work process displayed on the ENC chart (Jaseongdae container terminal) of ECDIS. 
Fig. 3에서 suction head를 이동시키면서 준설 작업을 수행할 때, 그 suction head의 수중위치를 일정한 깊이로 유지하면서 그 이동궤적을 수평 이나 일직선으로 유지하는 것이 매우 어려웠다. 이 때문에 suction head에 의해 해저토사가 더 많 이, 또는 더 적게 흡입되는 지점이 발생한 결과, 해저가 더 많이 파이거나, 또는 더 적게 파이는 매우 불규칙한 요철이 발생하였다.

준설작업에서 계획수심은 준설된 해저 상단부 분의 깊이로써 평가되므로, 실제 준설에서는 부 득이하게 더 많이 준설된 지역이 발생하게 된다. Fig. 3 에서는 준설작업 중 항시 준설선의 위치 및 준설 깊이를 정량적으로 모니터링하면서 과대한 준설이나 불필요한 준설이 발생하지 않도록 하 였고, 이를 위해 조위를 가감한 정확한 준설 깊이 가 자동적으로 산출, 표시되도록 하였다.

일반적으로 hopper 준설선이 계획된 route를 따라 이동하면서 해저토를 흡입할 때, suction head를 일직선상으로 이동시키도록 준설선을 제어하는 기술, 또한 준설된 해저면에 요철이 발 생하지 않도톡 준설수심을 일정하게 유지하는 기술 등은 준설작업의 시간 및 경비절감, 작업의 효율 등을 향상시키는 데 있어 매우 중요하다. 여기서는 이 문제에 주목하여 작업자나 관리자

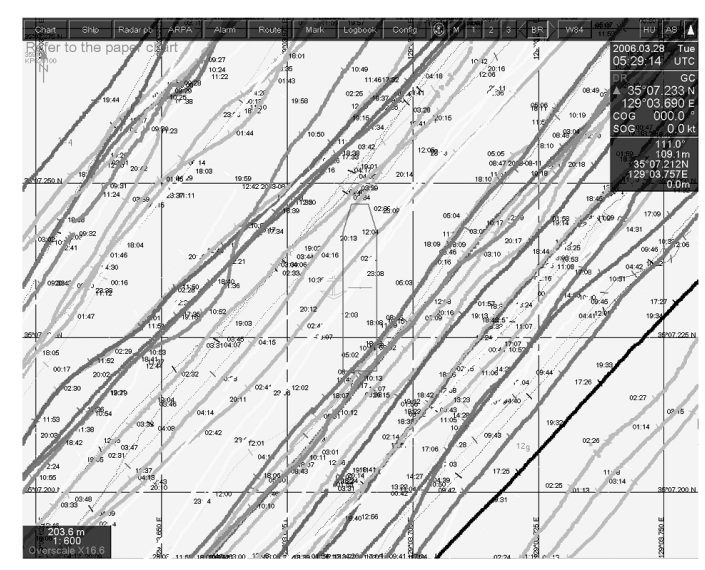

Fig. 4. Evaluation for the real-time monitoring information of dredging work process in the Jaseongdae container terminal of Fig. 3.
가 현재의 준설공정의 진도, 추가작업의 양 및 위치, 준설선의 route 재설정 등을 효율적으로 수행할 수 있도록 작업수역을 원하는 축적으로 확대하여 분석할 수 있게 하였는데, 그 결과의 일례는 Fig. 4와 같다. Fig. 4에서는 해당수역의 계획수심이 깊어 수회에 걸쳐 준설토를 퍼 올리 는 작업을 반복적으로 수행하고 있는 데, 이 때, 과거의 준설선의 준설시간과 궤적, 그 당시의 준 설 깊이가 컬러 밴드로써 도시되어 있고, 또한, 이미 수행된 각 준설 route 사이의 간격과 패턴 등을 동시에 정량적으로 파악할 수 있어 이후의 준설작업을 수립 및 관리, 평가하는 데 매우 유 효함을 알 수 있다.

준설공사가 완료된 후, 그 성 과는 수심도에 의 해 최종 확인되므로 수급자는 수심측량 결과를 기초로 수심도를 작성하여 수심측량 성과표와 함께 제출하여야 하는 데, 그 결과의 일례는 Fig. 5 와 같다. Fig. 5 는 준설공정에 대한 중간 성과도 를 나타낸 결과로써, hopper 준설선에 의해 준설 된 부산 자성대 콘테이너 부두 외측 수역에 대한 준설 깊이가 컬러 밴드로써 도시되어 있다. 이 준설 성과도로부터 준설이 계획된 수역의 $\mathrm{NE}$ 방향의 일부수역을 제외하고는 모든 해역이 비 교적 균등하게 계획수심까지 준설되어 있음을

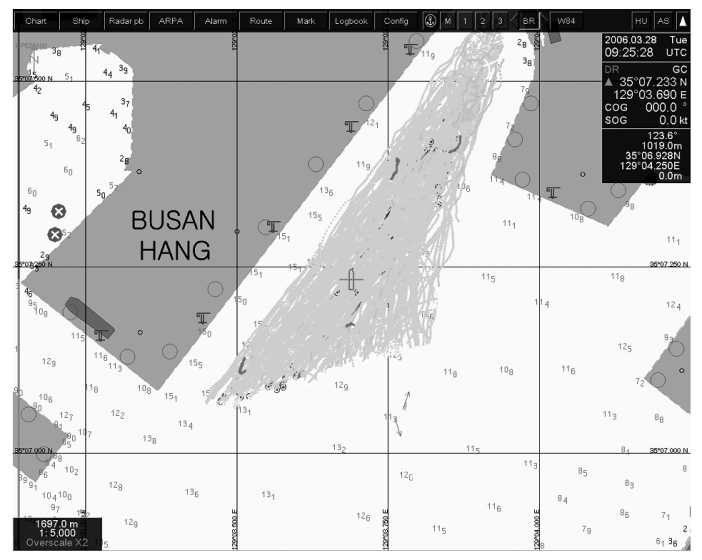

Fig. 5. An example of the dredging depth record to be submitted to dredging inspector in relation to the evaluation of the contract performance. 


\begin{tabular}{|c|c|c|c|c|c|c|c|}
\hline \multirow{2}{*}{\multicolumn{3}{|c|}{ Latitude }} & \multicolumn{4}{|c|}{$\begin{array}{r}\text { Date: } 2063.69 .29 \\
\text { (Datum: W84) }\end{array}$} & \multirow[b]{2}{*}{$\begin{array}{r}\text { SPEED } \\
\text { (kt) }\end{array}$} \\
\hline & & & & ongitude & & $\begin{array}{l}\text { COURSE } \\
\text { (deg) }\end{array}$ & \\
\hline 35 & 07.815 & $\mathbf{N}$ & 129 & 63.811 & E & 358.3 & 0.9 \\
\hline 35 & 67. 916 & $\mathbf{H}$ & 129 & ต3.81ย & E & 351 . & ต. 8 \\
\hline 35 & 67. 818 & $\mathbf{N}$ & 129 & 63.816 & $E$ & 352.3 & 0.7 \\
\hline 35 & 67.018 & $\mathbf{H}$ & 129 & 03.899 & E & 354.3 & 0.8 \\
\hline 35 & 07.019 & $\mathbf{N}$ & 129 & 03.808 & E & 355.5 & 0.8 \\
\hline 35 & 97.920 & $\mathrm{H}$ & 129 & 03.898 & E & 357.0 & 0.7 \\
\hline 35 & 97. 021 & H & 129 & 03.808 & E & 357.0 & 0.6 \\
\hline 35 & 07.022 & H & 129 & 03.808 & E & 357.5 & 0.6 \\
\hline 35 & 67. 923 & $\mathbf{H}$ & 129 & 03.808 & E & 357.5 & 0.6 \\
\hline
\end{tabular}

Fig. 6. An example of the dredging data obtained by the real-time monitoring of dredging process in the suction hopper dredger (Samyang - 7).

알 수 있다. 또한, 이 성과도에 해당하는 성과표 의 일례는 Fig. 6 과 같다.

Fig. 6의 성과표에는 작성시각(UTC(세계시) 기준)과 사용한 측지계(WGS84)를 명시하였고, 수급자의 요구가 있을 경우, 이 측지계는 ECDIS 상에서 자동적으로 일본측지계나 $\mathrm{TM}$ 좌표계로 써 변환 가능하도록 하였다. 또한, 준설공정의 성과는 ECDIS에 의해 해저토사가 suction head 에 흡입되는 시각과 준설위치의 위도 및 경도, 준설선의 침로 및 속력, 준설된 깊이 등이 자동 적으로 작성되어 harddisk에 수록되고, 필요에 따라 목적에 따른 처리 및 출력이 가능하도록 하 였다.

석션 호퍼 준설선(suction hopper dredger)에서 는 준설현장에서 suction pipe를 통해 고압으로 해저의 준설토사를 빨아올려 자신의 호퍼에 적 재한 후, 현측에 석션 파이프를 장착한 상태에서 준설선 자신이 자항으로 준설구역 밖으로 이동 하여 호퍼에 적재한 준설토사를 지정된 해양 준 설토 투기장에 투기해야 한다. 이 때, 준설선의 관리자의 입장에서는 호퍼 준설선이 준설현장 에서 퍼 올린 준설토사를 지정된 해양투기장까 지 정해진 항로를 따라 계획된 시간 내에 적법하 게 이동하여 투기하고 있는가에 대한 관리를 원 격지에서 수행할 필요가 있다. 본 연구에서는 이 문제에 주목하여 준선설의 이동에 따른 위치 데

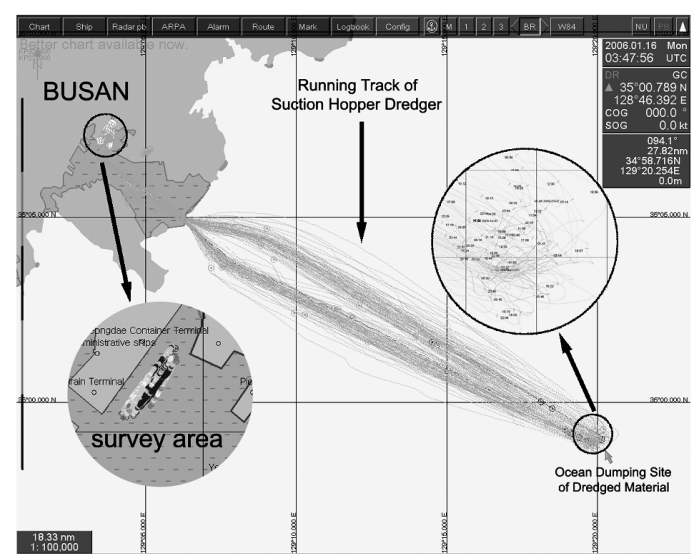

Fig. 7. Position and route tracking of the suction hopper dredger moving toward the ocean dumping site of dredged material located in the southern waters of Korea.

이터에 시간, 속력, 침로, 수심 등과 같은 항행 데 이터를 부가하여 관리자가 원하는 시간간격(최 소시간간격 $1 \mathrm{sec}$ )으로 ECDIS 시스템의 하드 디 스크에 수록되도록 함과 동시에 필요에 따라서 는 원격으로 무선 전송할 수 있도록 함으로써 호 퍼 준설선의 이동에 따른 동적거동을 실시간으 로 관리, 감독할 수 있도록 하였다.

Fig. 7은 부산 북항의 자성대 콘테이너 터미널 준설 공사장에서 준설된 준설토사를 남해안의 해 양 준설토 투기장 $\left(34^{\circ} 58^{\prime} .716 \mathrm{~N}, 129^{\circ} 20^{\prime} .254 \mathrm{E}\right)$ 에 투기하기 위해 삼양 7호가 2003년 7월부터 동년 12 월까지 왕복 항주한 항적을 중첩시켜 도시한 결과이다. Fig. 7에서 삼양 7호가 정해진 항로를 따라 정해진 해양 투기장에 적법하게 준설토사 를 투기하고 있는 상황이 ECDIS 정보에 의해 실 시간으로 추적되었고, 또한, 이 정보는 시간에 따른 준설선의 이동 위치를 정확하게 실시간으 로 제공하고 있어 준설선이 다시 준설현장에 귀 항하는 예정시간이 자동적으로 관리자에게 통 보됨으로써 현장에서 준설작업을 다시 계획 및 수행하는 데 매우 유효하였다.

2006년 1월에서 5월까지 5 개월에 걸쳐 인천 항에서 항만 증심을 위한 준설공사를 시행하고 있는 grab bucket 준설선 건웅 $\mathrm{G}-16$ 호에 의해 


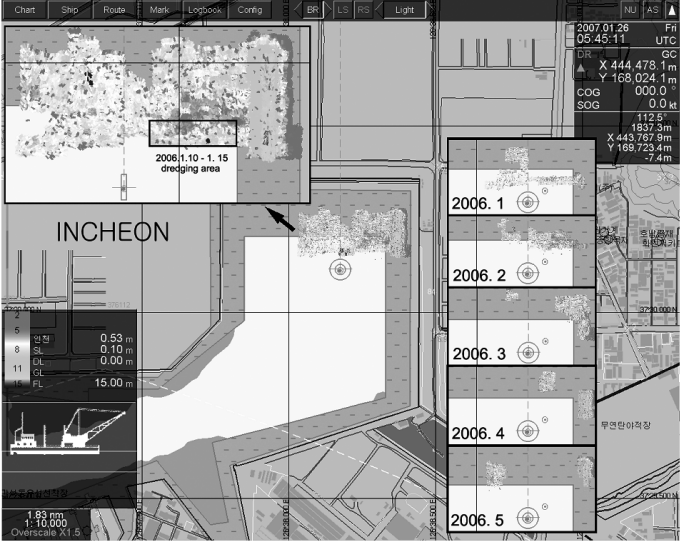

Fig. 8. Dredging depth records acquired by the real-time tracking of work process during the dredging operation by the grab bucket dredger (Kunwoong G-18) in Incheon Hang on January to May, 2006.

수록된 준설 데이터를 ECDIS 화면상에 나타낸 결과는 Fig. 8과 같다. 또한, 이 공사 기간 중에 수록된 준설 데이터를 Fig. 8의 우측에 월별로 구분하여 나타내었고, 이들 5 개월에 걸쳐 수행 한 준설 수심의 color band map을 확대하여 좌측 상단에 함께 나타내었다.

이 조사에서 사용한 grab bucket의 공중중량과 용적 은 경량급의 경우, 40 톤, $16 \mathrm{~m}$ 이었고, 중량급 은 60 톤, $8 \mathrm{~m}$ 이었다. 준설 수심의 측정 기준면은 준설작업을 수행하기 직전에 높이 약 $8.9 \mathrm{~m}$, 수평 폭 약 $6.5 \mathrm{~m}$, 수직 폭 약 $2.4 \mathrm{~m}$ 의 grab bucket을 완 전히 개구시킨 상태에서 이것을 수면까지 내리 고, 당시의 조석을 고려하여 설정하였다. 이와 같이 영점을 설정한 후, 권양하중이 약 120 톤, 권 양속력이 약 $20 \mathrm{~m} / \mathrm{min}$ 인 크레인 윈치을 조작하 여 드럼에 감겨있는 직경 $45 \mathrm{~mm}$ 의 wire rope에 연결된 bucket을 해중에 자유 낙하시켜 투하하 고, bucket이 해저에 저질 속으로 완전히 파고 든 상태에서 bucket 입구를 폐쇄시켜 해저의 저질 토를 bucket 내부공간에 완전히 수납한 후, 수면 으로 인양하면서 그 때의 bucket 투하 위치 및 투 하 깊이 등을 측정, 분석하였는데, 그 결과는 Fig. 9, Fig. 10과 같다. Fig. 9는 Fig. 8의 좌측 상

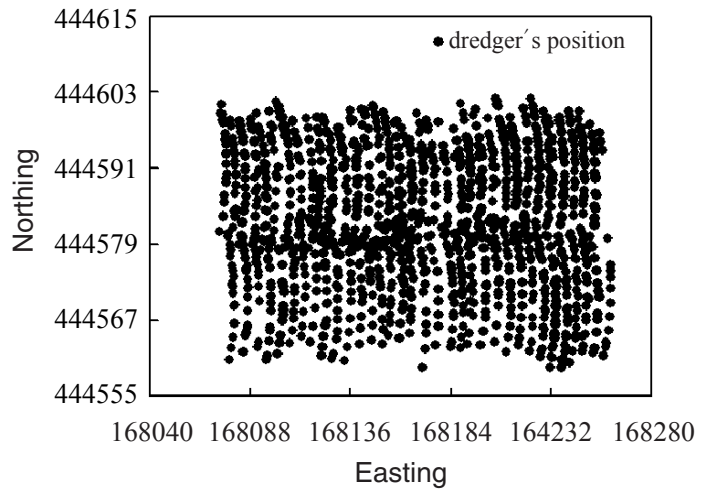

Fig. 9. Geographical distribution of dredging positions by the grab bucket dredger in Incheon Hang of Fig. 8.

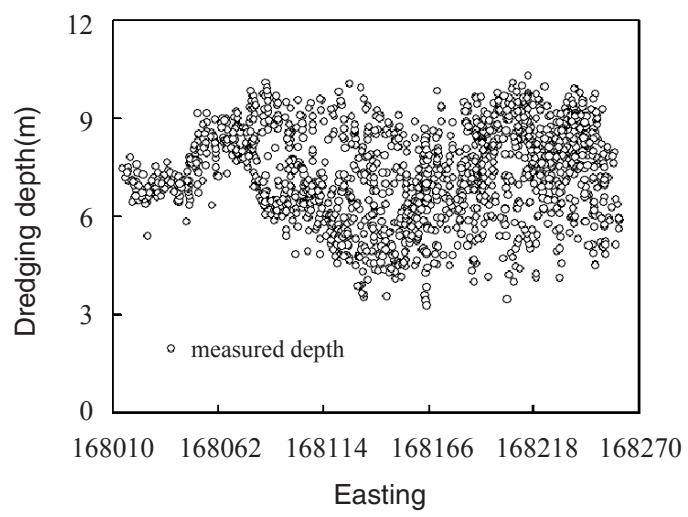

Fig. 10. Distribution of measured depths along the dredging route of the grab bucket dredger in Incheon Hang of Fig. 9.

단에 나타낸 2006년 1월 10 일부터 1월 15일까지 수행된 준설 작업을 보다 정량적으로 분석하기 위해 bucket이 투하된 지점의 지리적인 위치를 나타낸 결과이고, Fig. 10은 Fig. 9에 대한 grab bucket이 투하된 각 위치에 대한 준설의 깊이를 측정하여 easting 방향으로 정리하여 나타낸 결 과이다.

Fig. 9에서 grab bucket이 투하되는 위치의 궤 적은 활 모양의 형태를 나타내고 있는 데, 이 현 상은 준설선이 작업 현장에 진입하여 앵커나 spud를 내려 선체를 고정시킨 후, 준설 크레인을 선회시키면서 준설작업을 수행하기 때문이다. 
즉, 크레인의 회전 $\rightarrow$ bucket의 투하 $\rightarrow$ 준설토의 인양 $\rightarrow$ 토운선에 준설토 적재 $\rightarrow$ 다시 크레인 회전 등의 작업공정을 반복적으로 수행하기 때 문에 bucket 투하위치의 궤적은 원호 형태를 그 리게 된다. Fig. 9에서 준설선은 easting 168050, northing 444560 의 부근에서 easting 168250 , northing 444600 부근으로 이동해가며 준설작업 을 하고 있음을 알 수 있는 데, 이 작업공정에 대 한 모든 사항은 준설선이나 작업현장 이외의 다 른 장소에도 intranet이나 무선 internet을 통해 ECDIS 화면상에 동일하게 모니터링 되고 있기 때문에 준설에 관련된 작업자와 관리자가 모든 작업공정의 정보를 함께 공유할 수 있다.

그러나, Fig. 9 및 Fig. 10에서 크레인을 선회시 키면서 grab bucket을 해저에 투하하여 준설할 때, 각 투하 지점에 대한 해저의 저질특성에 따 라 bucket의 해저 돌입 깊이, 퍼 올리는 저질토의 양 등이 다르고, 준설선의 이동상태, 해황특성 등에 따라 준설이 직선상으로 수행되지 않는 경 우가 많기 때문에 해저 토사를 더 파고 덜 파는 요철현상이 불가피하게 발생한다. 이 문제를 해 결하기 위해 본 연구에서는 준설현장에서는 준 설선의 중심위치, 선상 크레인의 선회에 따른 bucket의 투하위치 및 깊이 등을 실시간으로 측
정하여 ECDIS 화면상에 함께 표시토록 함으로 써, ECDIS 화면상에 나타나는 정보를 토대로 크 레인 작업자가 다음의 준설작업을 어떻게 수행 할 것인가를 결정할 수 있도록 하였다. 또한, 여 기서는 grab bucket의 투하된 각 준설위치에 대 한 측정수심을 바탕으로 3 차원 지형도로써 작성 하였는 데, 그 결 과는 Fig. 11 과 같다.

Fig. 11은 Fig. 9 및 Fig. 10의 2006년 1월 10일 부터 1 월 15 일까지 수행된 준설작업의 수심 데 이터를 토대로 작성된 3차원의 준설해저 지형도 이다. 그림에서 easting 168080, northing 444560 의 부근에서는 준설수심이 $10 \mathrm{~m}$ 까지 달성되어 있으나, easting 168140, northing 444600 부근에 있어서는 준설 수심이 $5 \mathrm{~m}$ 전후의 값을 나타내어 앞으로 준설선을 어느 지점에 투입하여 얼마만 큼의 준설을 더 해야 하는가를 결정하는데 매우 중요한 자료가 된다.

한편, 2006년 1 월에서 5 월까지 5 개월에 걸쳐 인천항에서 grab bucket 준설선 건웅 $\mathrm{G}-16$ 호에 의해 준설된 지역에 대한 수심의 빈도 분포도는 Fig. 12와 같다. Fig. 8과 Fig. 12에 나타낸 준설 수 심의 빈도분포도에서 알 수 있는 바와 같이 월별 에 따라 준설해역의 해황, 조석, 준설선 및 준설 토 운반선의 출입 상황 등을 종합적으로 분석하
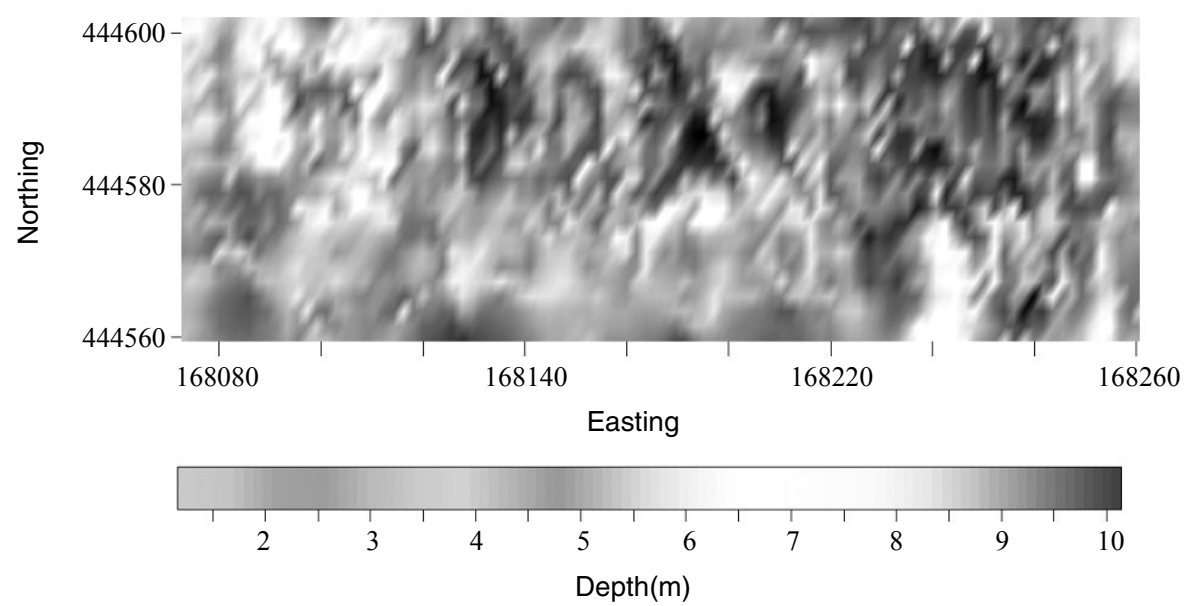

Fig. 11. 3D plot of dredging depths in Incheon Hang of Fig. 9. 


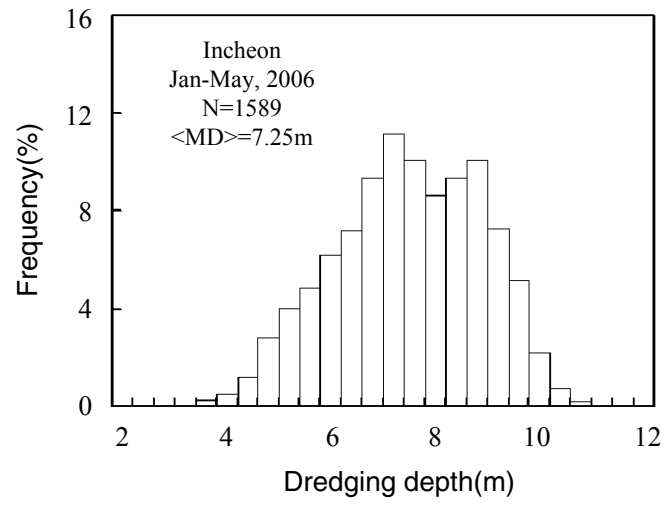

Fig. 12. Depth frequency distribution for dredging positions in Incheon Hang of Fig. 9.

여 수심 $4 \mathrm{~m}$ 의 해역에서 부터 수심 $11 \mathrm{~m}$ 의 해역 에 까지 준설선이 빈번하게 이동하면서 준설작 업을 수행하고 있음을 알 수 있다.

Fig. 12에 나타낸 준설 수심의 빈도분포에 관 한 정보를 토대로 국립해양조사원이 고시한 기 본수준면(약최저저조면)으로부터의 준설 깊이, 준설 폭 등의 수심도를 작성하면 향후 작업이 요 구되는 준설토량의 산출 및 확인이 가능하다. 이 와 같이 이미 준설된 구간에서는 파도, 조석, 조 류, 바람 등의 영향을 강하게 받으면 준설 해저 에 요철면이 발생할 수 있기 때문에 조위에 의한 심도보정을 하면, 준설 수심이 계획 수심에 미달 하는 구역이 발생하여 준설공정에 차질이 초래 되므로 이에 대한 주의가 요구된다. 또한, 인천 과 같이 간만의 차이가 큰 항구 에 있어서는 조 석, 기상상태 등을 고려하여 수심이 얇은 해역과 깊은 해역에 대한 준설시기 및 시간 등을 검토할 필요가 있고, 준설선, 토운선, 예선 상호간의 작 업상황을 서로 공유할 수 있는 모듈을 ECDIS 시 스템에 부가한다면 준설작업의 안전관리에 크 게 기여할 것으로 판단된다.

현재, 준설선이 해상에서 준설작업을 수행할 때, hopper 준설에 있어서는 준설시 여분의 물을 흡입한 후, 오수를 수중으로 배출하기 때문에 준 설 현장 부근의 수역에 대한 해수 오탁이 발생하
고, 또한, grab 준설시에는 bucket을 인양할 때, bucket으로부터 오니수가 유출되는 문제 등이 있 다. 이를 방지하기 위해 주위에 오탁 방지막을 설 치한 후, 준설작업을 수행하고 있으나, 대부분의 준설 현장에서는 실제적으로 해수의 오탁, 소음 및 진동의 발생, 오니수의 유출 등이 발생하고 있 다. 이와 같은 문제는 해양환경오염 등을 초래하 여 해저 부착생물에 대한 서식공간의 파괴하는 등 해양 생태계에 심각한 영향을 미치고 있기 때 문에, 이에 대한 실태를 실시간으로 평가하고, 제 어하기 위한 모듈을 개발하여 ECDIS 시스템에 부가시킨다면 더 효율적인 준설공정의 평가 및 관리가 실현될 수 있을 것으로 판단된다.

\section{결 론}

준설선의 작업공정을 보다 과학적으로 관리 및 평가하기 위한 기초연구로써, ECDIS 시스템 을 이용하여 hopper 및 grab 준선설의 작업공정 을 실시간으로 모니터링하면서 작업의 공정과 시간대별 준설 결과를 $\mathrm{ENC}$ 해도 상에 표시하면 서 이들 정보를 작업자와 관리자가 동시에 공유 할 수 있는 시스템을 구축하고, 실제로 현장에 적용한 사례를 분석, 고찰한 결과를 요약하면 다 음과 같다. 준설 작업의 모든 공정에서 수집되는 준설선의 이동궤적과 방향, 준설수심, 준설위치 등과 같은 준설정보는 일정 시간간격으로 외부 계측 시스템으로부터 전송받아 ECDIS 시스템 상에서 실시간으로 처리하였고, 이들의 결과를 $\mathrm{ENC}$ 화면상에 서로 중첩시켜 표시함으로써 준 설공정의 관리 및 평가를 현장에서 직접 수행할 수 있도록 하였다. Hopper 준설선이 계획된 route를 따라 자력으로 이동하면서 해저의 준설 토를 흡입하여 hopper에 적재하는 작업을 수행 하는 동안 준설선의 이동궤적, 침로 및 속력, 준 설 위치 및 깊이 등에 대한 작업공정요소를 실시 간으로 모니터링하여 $\mathrm{ECDIS}$ 의 $\mathrm{ENC}$ 화면상에 나타냄으로써 작업공정의 관리를 용이하게 하 였다. 또한, 준설작업 후, 자항으로 해양 투기장 
까지 준설토를 운반할 때, 준설선의 이동경로에 대한 동적 거동을 실시간으로 모니터링 함으로 써 준설토의 투기관리를 효율적으로 수행할 수 있도록 하였다. Grab 준설선이 bucket을 해중에 투하하여 해저를 준설하는 면적의 위치좌표를 bucket의 평면위치좌표, bucket의 크기 및 bucket 의 방향각 등을 이용하여 계산한 후, bucket이 투 하될 때마다 측정되는 준설된 수심을 컬러 패턴 으로 변환하고 준설 소해 해저면의 깊이를 실시 간으로 조석을 보정하여 $\mathrm{ECDIS}$ 의 $\mathrm{ENC}$ 화면상 에 나타냄으로써 작업공정의 파악을 용이하게 하였다. 이들의 연구결과로부터 ECDIS 시스템 은 준설작업에 있어 작업공정을 효율적으로 관 리 및 평가하는 데 필요한 각종의 정량적인 정보 를 실시간으로 제공할 수 있을 뿐만 아니라 준설 감독자가 모든 시간을 준설 현장에 상주하지 않 더라도 당해 준설작업에 부여된 과업내용을 체 계적으로 평가할 수 있는 준설진도기록을 실시 간으로 자동 생성시킬 수 있다는 점에서 무선통 신에 의한 정보의 원격송신에 대한 상용화 문제 가 해결된다면 향후 해상에서의 준설작업을 원 격으로 관리, 감독할 수 있는 시스템의 구현이 가능할 것으로 판단된다.

$$
\text { 사 사 }
$$

본 연구를 수행하는 데 있어 귀중한 각종 현장 자료를 제공해 주신 건웅산업(주) 관계자 및 마 린전자상사 김광식 사장님께 감사드립니다.

\section{참고문헌}

Darren, C., K. Kittaka and K. Soen, 1998. Reliable single frequency dual antenna processing system for marine dredging applications. www.novatel.ca/ Documents/Waypoint/Reports/Reliable.pdf, 1 - 11 .

IHC Systems BV, 2000. Dredge track presentation system(DTPS). 1 - 12 .

Jung, K.W., 2006. Real-time monitoring of grab dredging operation using ECDIS. Master thesis, Pukyong National University, 6-13.

Lu, G., G. Lachapelle and M.E. Cannon, 1994. Performance analysis of a shipborne gyrocompass with a multi-antenna GPS system. IEEE PLANS 94, 1 - 7 .

MECys, 2006. dredging management system operation manual. $1-158$.

SAM Electronics GmbH, 2007. Dredger technology. 1 - 8 .

2007년 7월 2일 접수

2007년 8월 7일 수리 